\title{
Response to the article: Profile and spatial distribution of maternal mortality
}

\section{Dear editor,}

The study describes the details concerning Maternal Mortality (MM), being one of the Millennium Development Goals its decrease until 2015.1 However, in the year 2015 , the maternal mortality rate in developing countries was 239/100 thousand live births and 12/100 thousand live births in highincome countries. In this context, according to World Health Organization (WHO), annually, more than half a million women die due to complications in the pregnancy-puerperal cycle. ${ }^{2}$ More than half of these deaths occur in hospitalizations arising from labor. The study highlights the concept of maternal mortality, which consists in death of women during pregnancy or puerperium, not including accidental or incidental causes. This mortality reflects life conditions, level of organization and quality of care provided to pregnant women. ${ }^{3}$ The study yet reports the creation of Maternal Mortality Committees in Brazil, which improved the records of deaths, once these risk situations affect, mostly, women with low access to healthcare and prenatal services of quality. ${ }^{3}$

Comparing the study carried out by Ruas et al. 1 with another study conducted in the city of Florianópolis, Santa Catarina, in the same period, we perceived that between the years 2010 and 2013, 7 maternal deaths and 593 deaths of women in reproductive age occurred. 4 Data obtained by DATASUS 4 demonstrated that the most influent obstetric cause was the indirect ( 4 deaths) versus the direct (3 deaths), which collides with the data presented by the study conducted by Ruas et al. ${ }^{1}$ Indirect causes of maternal mortality are those caused by treatable diseases, previously existent or during the gestation.
Thereby, the importance of prenatal is indubitable in order to prevent the occurrence of maternal death by indirect causes. Prenatal represents a fundamental role in the early detection of maternal and fetal pathologies, allowing measures of treatment that avoid higher harm to both pregnant women and fetus.2,3

Thus, we infer that the unfortunate reality of maternal deaths persists due to avoidable problems, with higher percentage in the city of Florianópolis, Santa Catarina, compared to numbers reported in the study of Ruas et al. ${ }^{1}$ The best adherence of pregnant women to prenatal services offered by public network consists in a trustworthy strategy to obtain the reduction of these rates.

\section{Author's contribution}

All authors contributed equally with the content. 
Gabriele Longo Cruz 1

(iD https://orcid.org/0000-0002-2857-4925

Miriam Rosa Paes 2

iD https://orcid.org/0000-0001-7329-0182

Aline Oenning Baggio 3

iD https://orcid.org/0000-0001-5903-0026

Chaiana Esmeraldino Mendes Marcon 4

(iD) https://orcid.org/0000-0001-7031-437X

1-4 Universidade do Sul de Santa Catarina. Av. José Acácio Moreira, 787. Bairro Dehon. Caixa Postal 370. Tubarão, SC, Brasil. CEP: 88.704-900. E-mail: gabrielelongo33@gmail.com

\section{References}

1 Ruas CAM, Quadros JFC, Rocha JFD, Rocha Neto C, Gregório RA, Piris AP, Rios BRM, Pereira SGS, Ribeiro CDAL, Leão GMMS. Perfil e distribuição espacial da mortalidade materna. Rev Bras Saúde Mater Infant. 2020 20 (2): 385-96

2. Hogan MC, Foreman KJ, Naghavi M, Ahn SY, Wang M, Makela SM, Murray CJ. Maternal mortality for 181 countries, 1980-2008: a systematic analysis of progress towards Millennium Development Goal 5. Lancet. 2010; 375 (9726): 1609-23
3. Troncon JK, Quadros ND, Leonel RPM, Cecatti JG, Surita FG. Mortalidade materna em um centro de referência do Sudeste Brasileiro. Rev Bras Ginecol Obst. 2013; 35 (9): 388-94.

4. Brasil. Ministério da Saúde. Sistema de Informações sobre Mortalidade. [acesso 17 set 2020]. Disponível em: http://tabnet.datasus.gov.br/cgi/sim/obtmap.htm.

Received on November 7, 2020

Final version presented on January 6, 2021

Approved on February 1, 2021 